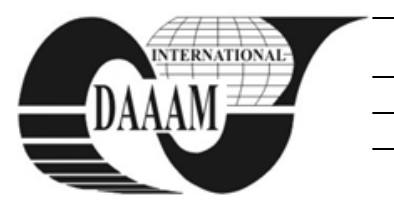

Annals of DAAAM for 2011 \& Proceedings of the 22nd International DAAAM Symposium, Volume 22, No. 1, ISSN 1726-9679 ISBN 978-3-901509-83-4, Editor B. Katalinic, Published by DAAAM International, Vienna, Austria, EU, 2011 Make Harmony between Technology and Nature, and Your Mind will Fly Free as a Bird Annals \& Proceedings of DAAAM International 2011

\title{
MACROECONOMIC EFFECTS OF EU FUNDING ON REGIONAL DEVELOPMENT
}

\author{
SOSTAR, M[arko] \& DEVCIC, A[nton]
}

\begin{abstract}
In this article are the main steps in measuring impact of the EU funds on the regional development in the European countries. Presented models and approaches are the key for the successful absorbing financial aid for the potential applicants. Quality projects and well educated people need to play a great role in regional development of every country.

Key words: EU funds, regional development, macroeconomic effects, absorption models

\section{INTRODUCTION}

The lack of a clear strategic vision at the national, regional or local level means that funds are easily spent on one-off projects that have no cumulative and long-term impact and are frequently not sustainable without continued aid. The fact is that regional development is depending on EU funds and quality project witch are implemented on the regional and national level. There are many models and approaches for measuring the impact of the $\mathrm{EU}$ funds on the regional development.
\end{abstract}

\section{THE FUTURE OF REGIONAL DEVELOPMENT}

Regional development is not only an efficiency issue in economic policy, it is also an equity issue due to the fact that economic development normally exhibits a significant degree of spatial variability. Regional development is about the geography of welfare and its evolution. (Capello \& Nijkamp, 2009). When we talk of regionalism, we mean striving for regional autonomy and emphasizing regional distinctiveness, which leads to conflicts on the spatial distribution of political power, a concept that overlaps nationalism and separatism. (Schrivjer, 2006)

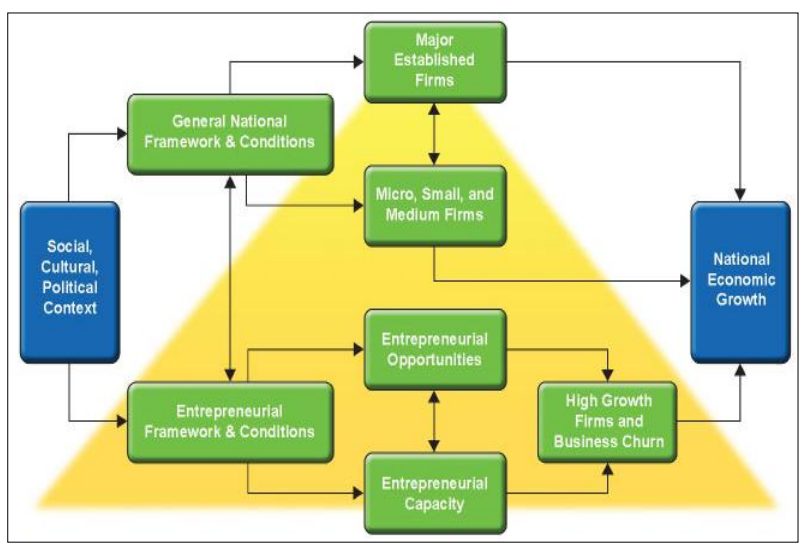

Fig. 1. Model of Regional and Economic Growth

The goal of Local and Regional Economic Development is to identify value-added potential in rural and urban regions or municipalities, and thereby to ensure employment and income and to create new jobs, while protecting natural resources in the interest of sustainable development. (GTZ- Society for
International Cooperation, 2006). The idea of sustainable growth is strictly connected with the notion of "regional development'. The mentioned concept was introduced with the degradation of the environment, demographic expansion and growing disproportion in socioeconomic development occurring in particular sides of the world as well as depleting natural resources. (Nermend, 2009).

The overall objective of regional development programs is to improve the capacity of inhabitants in certain geographic regions of a country to generate income. Factors generating cause and effect in regional prosperity and development are: biophysical resource endowment, geographical accessibility, human and social capital, demography, changing lifestyle preferences, space transforming technologies, new production technologies, expenditure on public infrastructure, business management and development, international events (McCall, 2006).

\section{IMPACT OF EU FUNDS ON REGIONAL GROWTH}

There are many models and approaches in measuring the effect of EU funds on regional development in each country. Economic analysis provides at least two types of approach to modeling and identifying the impact of structural policy interventions:

- An econometric, single equation, regression approach, based on the concept of convergence, which is, of course, closely related to the idea of catch-up,

- Simulation models. Simulation models use a combination of estimation and calibration to create a system that mimics or simulates the economy under study. A simulation may be partial equilibrium i.e. it simulates just one aspect of the economy or it may be general equilibrium in character in that account is taken of the variety of complex interactions between agents in the whole of the economy (Ministry of Finance Latvia, 2007).

\subsection{The econometric approach}

Eijffinger and Beugelsdijk (2005) simply examine whether convergence has occurred or not, using a standard growth equation approach. They regress the growth rate of real GDP on one-period lagged real GDP growth, two-period lagged real GDP growth and initial real GDP per capita, while correcting for institutional quality. The latter is done by including an interaction term, viz. the ratio of Structural Funds (SF) to GDP times the country-specific value of a corruption index. They conclude somewhat tentatively, first, that the SF has lowered the degree of regional disparity and, second, that this is independent of institutional quality i.e. a higher degree of corruption does not exert negative influence on the effectiveness of the SF. Therefore, they conclude that that the allocation of EU funds to the NMS will probably foster economic growth in these countries. From the viewpoint of 
simplicity, the Beugelsdijk and Eijffinger approach is to be preferred (Ministry of Finance Latvia, 2007).

\subsection{Simulation models}

A wide variety of simulation model types have been used to try to evaluate the ex-ante impact of EU funds, see e.g. Lolos (2001):

- Estimated/calibrated models: The main models of this category are: HERMES, HERMIN, QUEST II and ECOMOD. The HERMES model was developed by d'Alcantara and Italianer (1982), originally to analyze energy issues. Subsequently it has been adapted to evaluate the impact of structural funds for Ireland 1989 - 1993. In the Irish context HERMES was a disaggregated model (6 sectors) with a capacity to analyze the dynamic properties of the economy in the long run. The HERMIN model, initially developed by ESRI (Economic and Social Research Institute) in Dublin and in particular by John Bradley of ESRI (see references) can be regarded as a successor or extension of the HERMES model, and is explicitly dedicated to modeling the impact of the structural funds. Crucially, the HERMIN model allows for the treatment of both demand side shocks and supply side shocks HERMIN has been applied to Ireland (1989 - 1993 and 1994 1999, and for the latter period also to Portugal and Spain). For later periods it has also been applied to Poland and other Central and Eastern European countries, including Latvia and Estonia for ex-ante analysis of the 2004-2006 programming period and for most of the new member states for the 20072013 programming period. Typically, HERMIN models have had four sectors, where manufacturing and private or market services have been the 'actively modeled sectors' and public services and agriculture have been included without being explicitly modeled in a micro sense. In later versions of the model a fifth sector - construction has typically been included (Bradley, 2005). The QUEST II model, developed by DG ECFIN is a multicountry single sector model. The model uses a neoclassical production function for the supply side while the demand side is based on intertemporal maximization of firms and households. The ECOMOD model, developed by EcoMod/Free University of Brussels, is a highly disaggregated model; see e.g. Bayar (2007). The model has been used to evaluate the Funds impact for the 2007-2013 programming period for all accession countries, the full database of the EcoMod model covers 60 activities.

- Computable General Equilibrium (CGE) models and inputoutput models: CGE models are based on a strict microeconomic framework and rely on calibration while inputoutput models can be much disaggregated but may fail to catch dynamic factors- they are best for comparative-static analysis. For a discussion of research using these approaches see Lolos (2001). We can mentioned also two more models; Models for regions and Partial Equilibrium models: Some of the assessment in Rosenberg and Sierhej (2007) is partial Keynesian type analysis. (Ministry of Finance Latvia, 2007).

\section{CHALLENGES IN ABSORBING FINANCIAL AID}

There are many problems in absorbing financial aid from EU funds, especially in countries in development process. In this paper, we conducted research among 45 companies (beneficiaries of the EU funds) in Croatia to see what the main problems are. We wanted to determine the reasons for the small number of development projects approved for funding by the European Commission in Croatia. Research was conducted in the form of survey that contained nine possible answers. The question was: "What are the main reasons for the small number of applied projects towards available EU funds. The companies could choose more than one answer. The results of our research are from the companies' perspective and are presented in the table 1 .

\begin{tabular}{|l|c|}
\hline \multicolumn{1}{|c|}{ Main problems } & Number \\
\hline 1. Lack of knowledge within the company & 33 \\
\hline 2. Lack of expert assistance from outside & 10 \\
\hline 3. Lack of information & 5 \\
\hline 4. Very Demanding documentation & 31 \\
\hline 5. Large bureaucracies and procedures & 35 \\
\hline 6. Inability of co-financing projects & 14 \\
\hline 7. Lack of creativity and ideas in the company & 2 \\
\hline 8. Lack of interest for projects in the company & 3 \\
\hline 9. Other & 7 \\
\hline
\end{tabular}

Tab. 1. Main problem in applying projects toward EU funds

\section{CONCLUSION}

The regional development of each country depends on absorbing capacity from the EU funds. To have quality projects we need to have educated and informed people on the national and regional level, as well in the companies and other potential applicants. To maintain development and success every country need to use models for calculating absorbing power and impact of financial aid for projects on the regional development.

\section{REFERENCES}

Barry, F. (2000). The World Economy, "Convergence is not Automatic: Lessons from Ireland for Central and Eastern Europe", Volume 23, Issue 10

Bayar, A. (2007). European Commission, "Study on the Impact of Convergence Interventions 2007 - 2013", Available from: http://ec.europa.eu/regional_policy/sources/docgener/ evaluation/pdf/lithuania_benchmark_tfp_062007.pdf, Accessed: 2011-09-20

Bradley, J (2005). Regional Studies, "Does EU cohesion policy produce cohesion: the debate on the structural funds", Volume 40, Issue 2

Bradley, J., E. Morgenroth and G. Untiedt (2004). Scienze Regionali, "Macro-regional Evaluation of the Structural Funds Using the HERMIN Modeling Framework", No 3

Bradley, J., G. Untiedt (2007). GEFRA Working Paper, A Comparison of HERMIN, QUEST and ECOMOD”, No 3

Beugelsdijk and Eijffinger (2005). Journal of Common Market Studies, "The Effectiveness of Structural Policy in the European Union: An Empirical Analysis for the EU-15 in 1995-2001”, vol. 43(1)

Capello, R., Nijkamp, P. (2009), Regional Growth and Regional Development, Cheltenham, Northampton, ISBN: 9781847205063

GTZ- Society for International Cooperation (2006), Regional Economic Development in South-Eastern Europe, Eschborn

Lolos, S. E. G. (2001) "The Macroeconomic Effect of EU Structural Transfers, IIASA, Interim Report IR-01044/October

McCall, T. (2006). What do we mean by regional development, University of Tasmania, Cradle Coast

Ministry of Finance Latvia (2007). First stage report, EU funds macroeconomic impact assessment, Riga

Nermend, K (2009). Vector Calculus in Regional Development Analysis, Szczecin, ISBN: 9783790821789

Rosenberg, C. B. and R. Sierhej (2007). IMF Working Paper, "Interpreting EU Funds Data for Macroeconomic Analysis", No 07/77

Schrivjer, F. (2006), Regionalism after Regionalization, Amsterdam, University Press, Amsterdam, ISBN: 9789056294281 